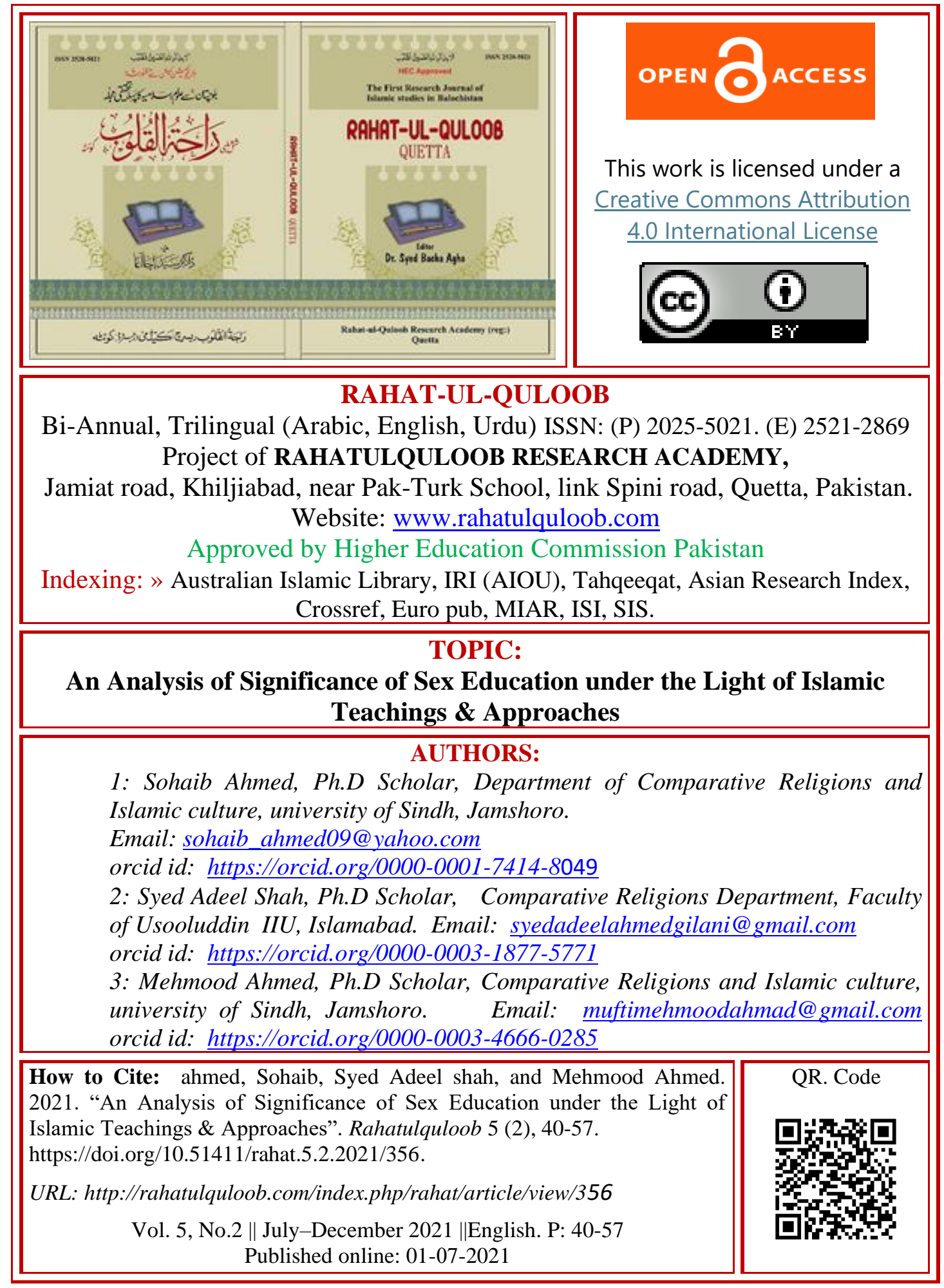




\section{An Analysis of Significance of Sex Education under the Light of Islamic Teachings \& Approaches}

\section{ABSTRACT}

${ }^{1}$ Suhaib Ahmed, ${ }^{2}$ Syed Adeel Shah, ${ }^{3}$ Mehmood Ahmed

Sex education is an important aspect of modern educational dynamics for a balanced society across the globe. As far as secular academics are concerned, there is conceptual and practical clarity about its provision with effect from particular grades in schools. Muslim societies have not yet designed their curriculum regarding it. This is the reason that the new generation is learning it from non-Islamic sources and spoiling their lives after taking part in forbidden way of sexual intercourse. In this study, the issue has been raised and discussed in detail in the light of the holy Quran and Hadith while the emphasis on the provision of sex education has been made so as to avoid unfair sexual practices in the Muslim societies including that of Pakistan. Sex educations at a global level, appropriate age of sex education, and attributes of the teacher of sex education have also been explained along with Islamic teachings regarding sexual affairs.

Key Words: Sex Education, Islam, curriculum development, secular academics Introduction:

Sex education is an important but critical part of any education system. Unless, sex education takes values, ethics, and instinctual desires into account, its goals will be incomplete and potentially dangerous. ${ }^{1}$ In the current education system, Muslim children are receiving secular sex education in schools and the media is also sending negative messages to them. Therefore, in terms of the formation of a Muslim education system, it should be kept in mind that the holy Qur'an also emphasizes the attainment of every useful education. Even in the time of the Holy Prophet, Muslim men and women did not hesitate to ask questions about their private lives regarding sexual issues. In this regard, there are a number of hadiths according to which the companions (Sahabiyaat in Urdu) used to attend the teaching sessions of the Holy Prophet (PBUH) and seek necessary guidance from him on very private matters. "Sexuality" is generally considered a flawed topic in Muslim society today. Talking about sex with children is considered disgusting. However, it should be kept in mind that "sexuality" is not a dirty word in terms of the prevailing conceptual trend. This is an important aspect of our daily lives. That is why Allah Almighty guides us in every aspect of our lives. The Qur'an describes creation, birth, family life, menstrual issues and even ejaculation. On the other hand, the Holy Prophet (PBUH), who was sent as a model of beauty for Muslims, taught his companions or followers in detail about the matters of sexual life. As an important part, the Islamic concept of "sexuality" is presented in this article.

\section{Research Questions:}

Following is some of the important research for this study:

(1) What is sexuality?

(2) Why is sex education important? 
(3) What is the reason for asking this question at this stage?

(4) Is sex education important in modern Muslim society?

(5) Who needs sex education?

(6) At what age this education should be provided?

(7) Who should be responsible to provide sex education?

(8) What are the authoritative sources of information about sex education?

(9) The most important question is what are the theoretical principles and rules for the application of sex education?

What is sex?

The term "sex" came into common use in the United States and Europe in the late $19^{\text {th }}$ century, when sexual studies in the anthropology, and the social sciences were discussed more seriously than ever before in this scientific and contemporary world. According to the Oxford English Dictionary, the word sexuality was first used as a term in 1836 when the $18^{\text {th }}$ century English poet William Cooper (1731-1800) used this term in his published collection of the literary works. ${ }^{2}$ However, according to Oxford dictionary, "sexuality means sexual activity between two people, in which both touch each other's body and sexual organs or intercourse takes place between them. ${ }^{3},{ }^{4}$ Sexuality is not only a term related to sexual activity, but it is also a term used to describe the interplay between the male and the female organs. This is a process that involves being physically together, touching each other and having sex with each other. But the legitimate Islamic concept of sexuality refers to intercourse between males and females for the continuity of the human birth after marriages. Allah Almighty says:

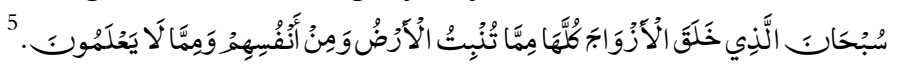

"Glory be to Him Who created pairs of every creation from what the earth grows and from them and from what they do not know".

Sexual desire is a desire like other natural and innate desires placed in man by Allah Almighty. As Allah Almighty says in holy Quran:

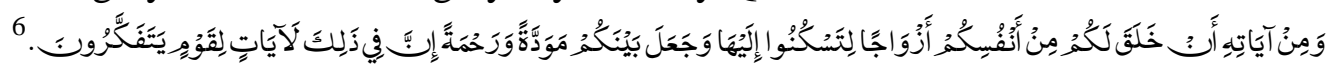

"And among His Signs one is that He created for you wives from among yourselves, so that you may find comfort in them, and He has placed between your friendship and kindness. Surely, there are signs for people who mull over them".

Man is not to be blamed for the emergence of sexual thoughts and desires. Allah Almighty has created every living being in pairs. As He says in holy Quran:

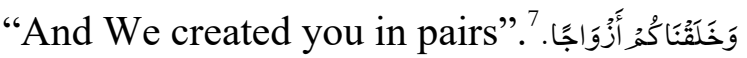

The creation of everything in pairs is a natural miracle that becomes the means of knowing God.

\section{The Islamic concept of sexuality and the process of birth}

The holy Qur'an deals with aspects of practical life, including sexual matters. According to the Qur'anic teachings, it is not permissible to satisfy sexual desire without marriage, 
and it is just as necessary for a Muslim to adhere to this limit in his practical conduct as it is to observe other Islamic limits in his conduct of life. This subject is stated in the holy Qur'an and Hadith in a very serious manner with regard to family life and family affairs. Islam does not consider a man or a woman to be a toy of sexual pleasure and entertainment, but guides them to satisfy this natural desire with certain rules and regulations within the legal framework to fulfill the will of God Almighty. That is why it has been ordered to fix punishment and limitation for the perpetrator of sexual intercourse without marriage, whereas after being bound in the sacred bond of wedding, it has been declared as a healthy act and worship. The Prophet (PBUH) once said that there is charity (voluntary offering) in every part of the body. His companions asked Hazrat Muhammad (PBUH) is the intercourse with wife also a charity or voluntary offering? He replied that "it is a sin to fulfill one's desires in a haraam way (without nikkah or marriage).8 In the same way, if it is done in a halal way (after marriage), there is a reward".

Man was created from sperm. The holy Qur'an sheds light on this process of creation and birth, and these teachings are a reflection of the sexual norms for human life. Creation and birth signify a spiritual purpose for the continuation of the universe, and the holy Qur'an contains a number of such related verses. Following are the Qur'anic verses describing the facts about creation and birth of human being.9

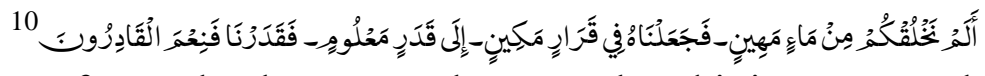

"Did We not create you from a lowly water? Then We placed it in a strong place to a certain extent. So, we fathomed or guessed, and We are good fathomers or guessers". In another place in Holy Quran, God says:

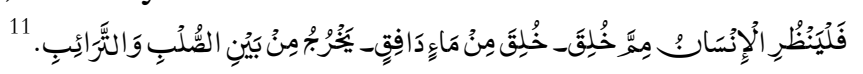

"So man must see from what he was created. It is created from rushing water that flows between the back and the ribs". It also sheds light on the male and female genitals. Therefore, according to the Qur'an, the male genitalia are considered the backbone and the female genitalia are defined as the ribs. Here it is important to know that the symbol of a man's strength is his spine. The spinal cord and brain serve as guides for the central nervous system and all bodily movements. ${ }^{12}$ Allah says:

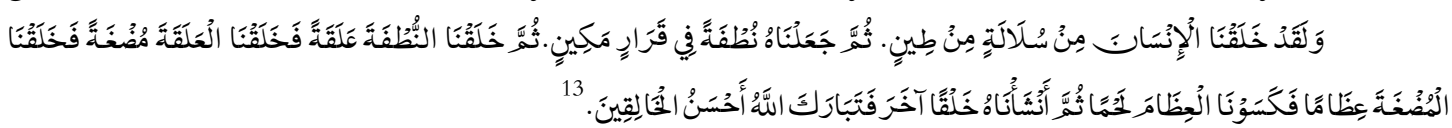

"And indeed, we created man from an extract of lowly clay. Then we made a drop and put it in a safe place. Then we made it a clot of congealed blood, then We made it a clot of congealed a small fragment, then we made it a bone, then we clothed it with some flesh, then we made it into another form. Blessed is Allah, the best of creators". Allah Almighty says in another place in holy Qura'n: 


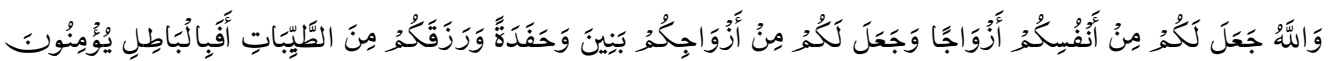

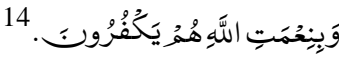

"And Allah has made for you wives from among yourselves, and has made for you from your wives' sons and grandsons, and has provided you with good (halah) provisions. So, do they believe in falsehood and deny the favor of Allah"?

In view of the above verses of the holy Qur'an, it is fair to say that education on sexual matters is not a "demand" when the body feels the need in social life, but to be aware of all the Qur'anic teachings is must. In order to understand this in a better way, it is necessary to put forward the practical examples presented by the Messenger of Allah and his companions (Sahaba in Urdu).

\section{Sex Education}

Sex education is a broad term used to provide information about human sexuality, anatomy, sexuality, sexual intercourse, and other sexual aspects of human behavior. Sexual education covers the structure of the human body, its organs, sexual function, family life, sexually transmitted diseases and pregnancy. It also includes social, moral and religious ethics. Learn how to deal with the pressure of peer attraction, the rise of sexual desire and its recurrence. What is the time of puberty? What physical changes occur during puberty? How does the formation and birth of a fetus take place? What are the necessities of family life? What are the stages of the birth process? What are women's menstrual problems and their solutions? What are the problems before and after menstruation and their solutions? What is the journey of sexual intercourse? What are the legal and illegal methods of sexual intercourse? What does sexual intercourse have to do with marriage and divorce? Therefore, sex education is essential for living a proper, reasonable, healthy and happy life. Getting sex education is very important to be aware of the right age and legitimate way to have sex. This is an important lifelong duty and responsibility performed by families, religious institutions and secular educational institutions. In order for an individual to have a proper place and status in his or her family and society, he or she must be emotionally, psychologically and socially trained, and other elements of this training include sex education. The main purpose of sex education is to shape the relationship between individuals and families in a positive and useful way. One of the reasons for family and social problems in contemporary Muslim societies is that "sexuality" is considered a dirty term. It will be considered an act and the mood of catholic religious leaders that will begin to emerge in Muslim societies as well. Islam, on the other hand, presents a balanced concept and allows it in both legitimate ways for both consolation and birth. In Islam, the divine wisdom regarding the creation of man and jinn is clearly stated:

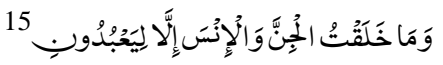

"And I did not create the jinn and mankind except that they should worship Me". All matters of a Muslim's life take place in submission and obedience to the commands 
of Allah Almighty. These commands cover all matters of life, including sexual intercourse. Sex education, if useful, is new to the child. Adopts conditions, accepts new ideas and introduces different kinds of moral values. Sexual misconduct is on the rise in the new generation nowadays. There are many reasons for this such as:

The pressure of attraction of the opposite sex becomes irresistible.

This attitude has become so common that since everyone is suffering from it, there is nothing wrong with it.

Immediately after puberty, the desire to move forward by building sexual strength and skills is growing rapidly.

There is a severe lack of control over sexual desires.

Educational institutions lack guidance on engaging in other positive and useful activities instead of pursuing sexual desires.

There is a lack of love and admiration in the home.

Detachment from the home leads to the formation of relationships outside. From cohosts in co-educational institutions, to sex scenes in TV commercials and other programs, and from what is being discussed on TV news and talk shows, minors are everywhere. Sexual pressure is coming. Contemporary music, its poetry, and scenes filmed on it are also contributing to the increase in children's sexual orientation. Under this situation, it is safe to say that sex education is just as important for older people as it is for children over a certain age.

\section{Global sex education}

Sex education has become an emergency for a number of reasons. Of these, AIDS is the most alarming. In many African nations where AIDS has become a pandemic, medical experts have called for the promotion of sex education to protect the health of citizens. In this regard, some international organizations have also taken practical steps. Planned Parenthood is on top in this. ${ }^{16}$ Despite the prevalence of sexual misconduct in the West, most parents try to keep their children away from sexual activity. In the past, under the supervision of former US President George W. Bush, the Department of Education created a special curriculum called "abstinence-only". The curriculum instructed children to abstain from sexual activity until puberty or marriage. They were not given any information about contraceptives as awareness of this information leads to sexual misconduct in minors. ${ }^{17}$ In the United Kingdom, sex education has been made compulsory for students in secondary and higher secondary education, but parents have the option of whether or not to include their children in this education. The system contains information on the physical and emotional changes that take place in the body with the formation of the fetus and puberty. Sex education is a hot topic. Sex education has been part of the curriculum in France since $1973 .{ }^{18}$ There is a ban on 30-40 hours of sex education for eighth and ninth grade students in all schools. The Danish government adopted the slogan "Lang leve de liefde" (love lasts forever) in 1980, and has since begun teaching young children skills related to their sexual activity and health care.19 And biology lessons in high school are taught in almost all schools. 
About half of all primary schools also teach sex and fetal lessons to young children. The curriculum seeks to develop skills in the birth process, ethics, practice, communication and understanding. ${ }^{20}$ Sex education programs in Asia are still in various stages of development. Indonesia, Mongolia, South Korea and Sri Lanka have a regulated system of sex education in schools. In Malaysia, the Philippines and Thailand, it is still in the experimental stages. No such system has been introduced in Myanmar and Nepal. ${ }^{21}$ In the education system of Pakistan and Bangladesh, no significant practical steps have been taken so far with regard to sex education in the existing curriculum. In these madrassas, while teaching sex to the students regarding social, moral and religious ethics, methods of protection from the pressure of the opposite sex, increase in sexual feelings and emotions, determining the age of puberty, what happens in the body during puberty. To be fully aware of changes, fetal formation and childbirth, need and importance of family life, birth process, genitals and related issues, menstrual and postpartum issues, marriage, divorce and physical hygiene etc. And the attempt is made. This information does not seem to be sufficient. The curriculum needs to be restructured in such a way that it can be modified according to the more modern conditions so that students may be practically protected from sexual misconduct. In Africa, the focus is on AIDS prevention and control. With the support of international NGOs and the World Health Organization, most African governments have begun work on AIDS education education projects. Under these plans, the basics of AIDS precautions are made known to the basics. (A) Avoid sexual misconduct. (B) Be honest. (C) Use condoms. ${ }^{22}$

The general approach to sex education is to discourage unsafe sex behaviors that may increase the risks. The main goal of these projects is to increase the individual's knowledge of decision making regarding sexual activity in private life. If a person discusses sexual matters in front of a child without a formal educational program and parental permission, it can not only be considered unreasonable and inappropriate, but it can also be interpreted as questioning the child's upbringing.

\section{Sex education for young people}

Every public and private educational institution in the United States provides sex education from grade II to grade 12. Every year since 1990, 2 billion has been spent on this education. Teachers are advised not to teach it to children. What ethics are taught about sex education or what is wrong and right about sex education. On the contrary, teachers are advised to impart information to children about the technical aspects of sex education. And after being informed of the birth process, they are taught how to avoid sexually transmitted diseases and how to avoid pregnancy at a young age. The focus is on "safe intercourse" as AIDS progresses. Sex education under the influence of secular education systems is in no way compatible with the moral system of Islam. Despite spending 2 billion a year on sex education, there has been no reduction in the number of cases of sexual misconduct among minors and pregnancies among minors in the United States. There has been no positive change in habits. According to the 
president of the Children's Defense Fund Marion Wright Alderman, "10 out of 20 girls are sexually active but only 4 of them use birth control pills. Two of them get pregnant and they give birth". According to US researcher John Hawking, sexual activity is $43 \%$ in 17 -year-old girls, $46 \%$ in 16-year-old girls and $29 \%$ in 15 -year-old girls. It can be estimated that $80 \%$ of girls entering college chastity is tarnished. Even going to church does not have a positive effect on their character. Therefore, in the light of Islamic teachings in the present era, sex education has become indispensable for the formation of a happy social life. It should be noted here that faith in the Creator must be strengthened in the minds and hearts of the students before teaching the interpretation of organs and physiology. It is said that "everything is possible without God" and this means that lack of knowledge about the Creator and lack of faith in Him is the only way to commit black acts. Therefore, the younger generation should be given sex education in the light of the holy Qur'an and Hadith. Their other problems will be solved automatically. Sex education derived from Islamic teachings will reveal not only morality but also information about physical health and well-being.

\section{The role of Muslim parents}

Just as parents have a primary responsibility to inculcate Islamic teachings in their children in terms of religious beliefs, faith, social values, culture and morals, so they do play a key role in maintaining their physical upbringing and health. In Non-Muslim societies or in these dysfunctional Muslim societies, the role of parents becomes more sensitive. In the holy Qur'an, Luqman's advice to his son is described in detail. One of them is:

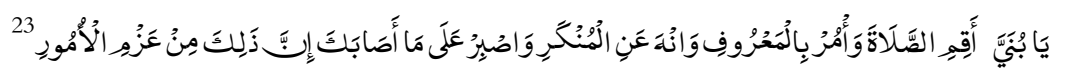

"O my little son! Establish the prayer and enjoin what is right and forbid what is wrong, and be patient over what has befallen you".

It is important for parents to keep their children away from evil habits. These include alcoholism, drug abuse, sexual misconduct, etc. In Muslim societies, parents have sex with their children through schools and madrassas. Educating is an important duty. This can also be done through imams in mosques who can teach sex in the light of the Qur'an and Hadith while arranging lessons. The effectiveness of this role of imams became clear when Richard Boucher, Assistant Secretary of State for Central and Asian Affairs, said after visiting Bangladesh that dowry has been reduced in Bangladesh under the influence of teaching and preaching of mosque imams, a surprise in religious extremism. ${ }^{24}$ Decreased to a nasal extent, Drug use has dropped dramatically, and sexual misconduct has led to a significant reduction in AIDS cases.If this can happen in Bangladesh, then it can happen in the whole Muslim world. But it should not be left to educational institutions, but should start with home-based education by parents before schooling. If sex education is considered to be dependent on educational institutions by Muslims living in Western countries, it will certainly not be in accordance with Islamic principles. No physical information related to married life should be given 
unless the person is married. Parents should be fully prepared for this and in this regard research and analysis of Islamic teachings one should not feel any kind of shame. Every member of the society and family should provide sex education according to the age and needs of the children according to their options and their position. Parents need to be more proactive in this regard because they are more responsible for inculcating in their children the ability to make the right decisions at every stage of their lives. They themselves do not take any practical steps regarding their children's sex education and consider it the responsibility of educational institutions and the media. However, in Islam, everything that leads to unlawful acts is haraam. Therefore, it is the responsibility of parents to keep their children away from devices and means that could provoke their sexual desires and emotions. In this regard, children should be made to feel that they are different from non-Muslim children in terms of their religion, values and practical character. They should refrain from drinking alcohol, eating pork, using drugs and engaging in premarital sex. At the same time, their consent should be sought in choosing a life partner. The responsibility of the father for the boy and the responsibility of the mother for the girl are very high in this jam. The Holy Prophet said:

$$
25
$$

The person who has children should have a good name, take care of his education and training, and when he becomes an adult, he should marry him. The sin will be on his parents.

\section{Appropriate age for sex education \& marriage}

Sex education should be given in a phased manner with physical and mental upbringing. First of all, parents should educate their children according to their age. Instead of teaching sex to all children at once, they should introduce sex education according to age requirements in individual sessions with children. Students of the holy Quran can be given information on topics of sexual nature. When a child is reciting such verses on menstruation, intercourse, homosexuality, etc., he can be given information in the form of facts related to these matters. In the same way, when a child is an adult, he can be taught about the importance of cleanliness in certain sexual matters. A child of six or seven years can be taught how to clean his body after using the toilet. Eleven to thirteen-year-old children can be taught how to take a bath (ghusl) as well as how to take care (ghusl). For this, it is necessary to have a good relationship between parents and children. At the same time, as parents, their own children there should also be contact with teachers. Parents should study Islamic literature on sexual matters. They should know about Quranic verses, hadiths and the opinions of scholars on specific topics (family planning, sex). Homosexuals can get this education through a decent and effective person or a teacher of religious studies. Her personal study should include books on the Islamic aspect of sex education. But it should be noted that it is not enough to educate another person or provide books to children. As a parent, they should 
always be ready to answer the questions of their daughter or their daughter. With Janit so that if they feel reluctant to answer the children's questions, they can guide them to an authoritative book or individual to find the answers to their questions. In the family environment, the eldest sister is responsible for the younger sisters and the eldest brother is responsible for the younger brothers. If this does not happen then the father is responsible for educating his sons while the mother is responsible for educating her daughters. If this is not possible, it is imperative that the female medical teacher for the girls and the male medical teacher for the boys should be among the teachers in the school. The curriculum should be tailored according to the age of the students and Separate classes should be ensured. There is no need to explain to a five-year-old how he or she came into the world, or to teach a fifteen-year-old how to use a condom. Part of the curriculum can be: Sexual arousal, puberty, physical changes during puberty, the need and importance of family life, reproductive system, male and female genital information, menstruation for girls, menstrual related medical and psychological issues, pregnancy, fetal Birth and childbirth, sexually transmitted diseases such as AIDS etc. and related Islamic teachings, mental, emotional and social aspects of rhetoric, social, sexual and religious ethics related to sexuality, attraction of the opposite sex Ways to avoid stress, etc. Islamic teachings on various aspects of human sexuality are very clear. There are many hadiths of the Prophet (peace and blessings of Allah be upon him) available on these matters which show that he did not neglect this important part of his life. It gives a sense of the impact that educating students on issues related to puberty has on their physical and mental health. No one can deny the fact that the effects of both children and adults, Influenced by traditions and values.

\section{Sex education after marriage}

From an Islamic point of view, marriage is essential for the formation of family life. For Muslims, sexual intercourse is permissible only after marriage between husband and wife. The existence of healthy sex is very important in this regard. Islam encourages strong sexual desire for procreation. Therefore, Islam encourages marriage as a moral shield to fulfill sexual desire. The purpose of marriage is not only to meet the expenses of the man and woman, to satisfy their sexual desire or to increase the human race, but it is also a spiritual and moral act which is also supported by Allah Almighty. Love and friendship between the couple is an important aspect of this bond. Immediately after marriage, the couple gets a new place in the society, their children and family as well as their responsibilities regarding massage increase. Marriage The aim is to create love between women and men and to meet their natural needs through friendship. There is no better example of human relationship on earth than the harmony between husband and wife. ${ }^{26}$ This relationship is so important that Allah Almighty has declared it as one of His signs.

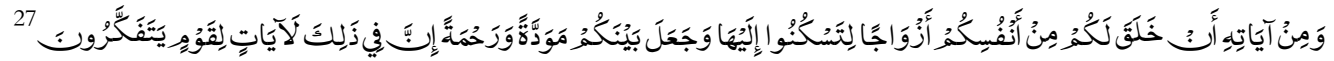

"And among His signs is that He created for you wives from among yourselves, that 
you may find comfort in them, and He has placed between your friendship and kindness. There are signs that reflect".

In a second place in holy Quran, there is also the command of Allah Almighty regarding the creation of man.

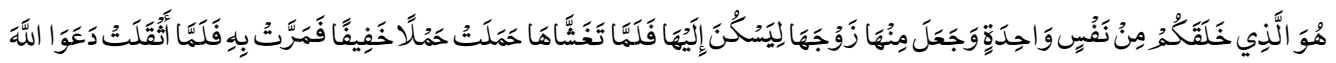

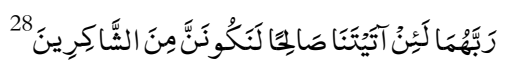

He it is Who created you from a single soul, and made for it its mate that it may be a source of comfort to it. She carried him on her way, then when she became heavy, they both prayed to Allah, their Lord, that if You give us a healthy baby, we will surely be among the grateful. Allah Almighty also declares that

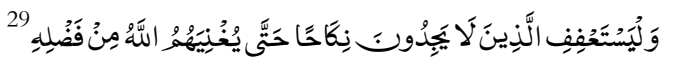

"And let those who have no means of marriage beware of the forbidden, until Allah enriches them of His bounty".

Emphasizing the importance of marriage, the Holy Prophet said:

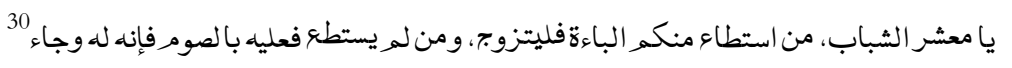

"O folks! Whoever of you has the power of marriage should get married and whoever does not have the power of marriage should keep fasts. This is because this desire will break the soul". When a person reaches the threshold of maturity or comes of age, can live independently, can fulfill the needs of marriage, then he can get married. After puberty, every person should stay away from sexuality untill he gets married otherwise, there is a risk of developing or having illicit sex with the opposite sex. Due to the lack of this concept of fair and unfair (haraam and halal), approximately, one million girls in the United States become mothers illegally. ${ }^{31}$ Unfortunately, in Pakistan, the statistics in this regard do not exist. It is the husband's responsibility to inform his wife of his likes and dislikes regarding sexual matters and never to compare her with any other woman. She should not only remain a recipient but also play a full and dynamic role in this regard so that her husband can get satisfaction and happiness from this process. It should be noted that sexual intercourse is an expression of love without which emotional satisfaction is impossible. Without love, sexual intercourse becomes boring. ${ }^{32}$ That is why women consider forced sexual intercourse in marriage to be equivalent to rape. According to researchers, Islamic teachings also include the rule that the husband should not attack his wife like a beast, but it is necessary for the husband to comfort his wife as well. The hadith about discharge can also be put into practice with the consent of the wife, as it may hinder the wife's satisfaction or her desire for children. ${ }^{33}$ Therefore, the Islamic concept of sexuality is based on nature, ${ }^{34}$ in the light of which the human body is seen not as a sexual machine but as an amazing creation of God Almighty. All forms of intercourse between spouses are permissible in Islam, except for backsliding. In the holy Qur'an, God Almighty says:

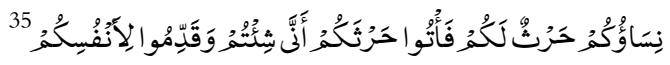


"Your wives are your property, so use your property as you wish and send forth for yourselves".

If a particular organ of one of the spouses suffers from a disease, it should be treated first. Similarly, Muslims are not allowed to have sexual intercourse during menstruation because it causes pain to women during this period. Allah Almighty says:

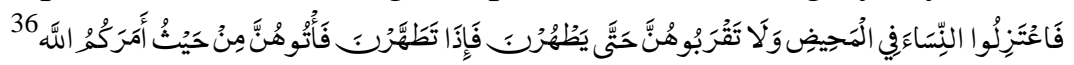

"Stay away from women during menstruation and do not go near to them until they become pure, and when they take a bath (do ghusl), come to them from where Allah has commanded you".

In Ramadan, sexual activity is allowed only during the night, as the day time is reserved for fasting. Allah Almighty says:

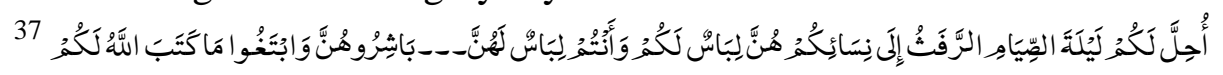

"It is permissible to have intercourse with wives at nights in the month of fasting. They are attires for you and you are attires for them. Now have sex with them and ask for what Allah has written for you".

On the contrary, no such exception has been granted during the days of Hajj. Allah says in the holy Quran:

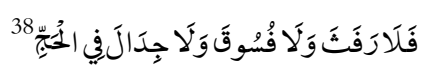

"During Hajj, there should be no sexual acts, no disobedience and no quarreling".

There are many hadiths related to these matters. The Holy Prophet (PBUH) himself had never revealed the sexual matters of his life, but in spite of this, he was known as a loving, expressive and sensitive husband. In many hadith, the Prophet (PBUH) encouraged people to incline their minds before sexual activity and to speak words of love and affection. These hadiths give a clearer picture of the sexual act in which the husband is commanded to abstain from sexual intercourse in this way. Make a contribution by which the wife gets sexual satisfaction before the husband.39

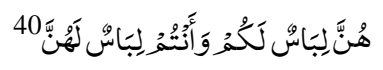

This hadith shows that sexual dissatisfaction on the part of one of the spouses is considered a legal justification for divorce. Because attire is very close to the human body, the two are also very close to each other. Outfits can be worn at any time so both of them should be available for each other at all times. Attires are a beauty or a cause for human beings so both of them are a source of comfort and adornment for each other. The new generation should be encouraged to get married. This will ensure the satisfaction of human nature and the moral well-being of the society in a positive way. Anxiety about sex education: Sexual activities without wedding Every human being has sexual feelings and it is these sexual feelings that bring two people closer in return for which a marital relationship is established between them. In addition to marriage, there can be sexual relations between men and women, which are highly encouraged in the modern world. After the Industrial Revolution in Europe, 
the concept of family life and the purpose of marriage have completely changed. Material gain has been made attractive to married and unmarried people. Women are now encouraged to strengthen themselves financially and gain independence from male guardians. Feminist NGOs say men should no longer be subjugated merely to meet economic needs. Sexual freedom has been opened for women through contraceptives and modern abortion methods. The number of unmarried underage girls in the United States is growing. According to the American Census, the number of married couples out of $111,100,000$ couples is 52,200,000. The number of unmarried couples has decreased by $52 \%$ in the last five years. ${ }^{41}$ Having sex without marriage is not allowed in any religion. In this regard, Islam has commanded to stay away from those acts which open the way for committing illicit sexual activities. Islam allows mixing of men and women only if they are mahrams of each other. ${ }^{42}$ Even in secular societies, girls like to live with girls and boys like to live with boys. Adultery and fornication is a crime not only against the individual but also against the society because it insults the marriage bond. Therefore, Islam has declared it unfair (haraam). ${ }^{43}$ There is a clear declaration of its sanctity in the holy Quran. The Prophet (PBUH) mentioned it in Akbar al-Kabayr, and in this regard there is also an incident relating to a person who came to him and asked for permission to commit adultery. Holy propher (PBUH) replied him that "the one [woman] you would commit adultery, is someone's mother, sister, daughter or wife. Just as you won't like that someone may commit adultery with your mother, sister, wife or daughter, so no one else would like someone to commit adultery with these relations (mahrams)". The person understood prophet's words and he repented. On the occasion, the prophet (PBUH) prayed for his forgiveness. The Bible also forbids adultery and prescribes stoning as punishment. According to bible, "Let the people of his city stone him to death, for he has done wickedly among Israel to commit fornication in his father's house". ${ }^{44}$ Islam also commands to stay away from adultery:

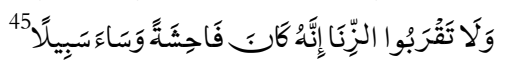

"And do not approach to adultery. Indeed, it is the greatest indecency and the worst way". The teachings of these two inspired books (the holy Quran \& the bible) show that without marriage, sexual activity is not only unfair (haraam), but also everything that could precede this heinous act. Therefore, it is unfair (haraam) to commit adultery including that of wearing loose clothing, adopting semi-nude fashion, mixing of men and women, and watching nude movies. Men and women are free to fulfill their social, educational, economic and other responsibilities. But Islam has set some rules for them. Nudity has led to a rise in sexual arousal in Western society, which in turn has led to an increase in sexual appetite among young people, and incidents of gang rape, sexual harassment and even murder have reached to an alarming extent. Moreover, rape, the end of family life, mistrust between spouses, etc. have become a wake-up call for modern societies. Islam has closed all the doors of pornography to prevent this 
worst social situation. Men are generally more inclined towards women, so the women are commanded by Allah Almighty to wear hijab:

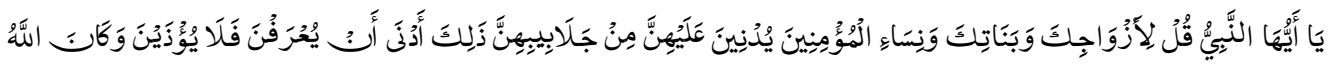

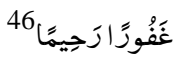

"O Prophet! Ask your wives and your daughters and the women of the believers to hang some of their cloaks over themselves. It is nearer that they should not be harmed if they were recognized, and Allah is Ever-Forgiving, Most Merciful".

This has closed all avenues for the emergence of unforeseen circumstances in society and for people to fall prey to their sins. Like women, men have been ordered not to wear clothing that attracts women. Both are commanded to create modesty in their eyes and to protect their honor. Allah says in Quran:

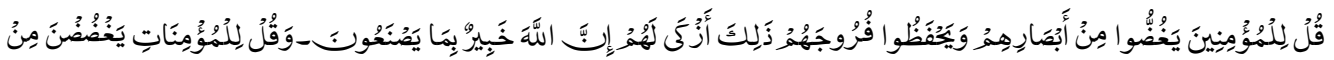

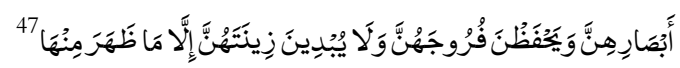

"Tell the believers to lower their gaze and guard their private parts, it is purer for them. Surely Allah is Aware of what they do. And tell the believing women to lower their gaze and guard their private parts and not to display their adornment except that which may be manifested in it".

Islam also commands children to be protected from this notion and to maintain their natural innocence. The Prophet (PBUH) commanded to separate the beds of the children who reach at the age of 10.48 If Western society wants to get rid of the sexual misconduct within itself, it has no choice but to follow the Islamic teachings regarding maintaining 'shame and modesty' in order to strengthen family life. The trend of homosexuality is also increasing in the western society. There are some people who want the society to accept homosexuality. There is an attempt to protect this practice through legislation, which is causing a lot of problems. Homosexuality is a major natural obstacle to the growth of the human population. The people of Hazrat Lot (God be pleased with him) in majority used to commit this act.49 In this nation, instead of natural intercourse between husband and wife, immortality was prevalent.

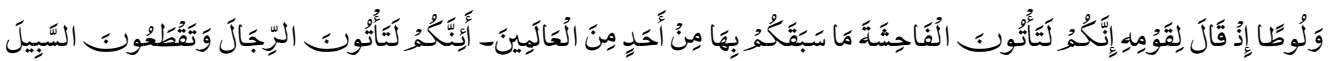

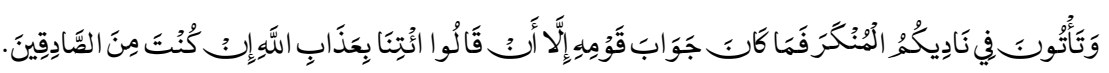

"And when Hazrat Lot (AS) said unto his people: Surely you are committing indecency which none of the nations before you have committed. Do you really come to men and cut off the way and do evil in your gatherings? So the answer of his people was only that they said: Bring upon us the chastisement of Allah, if you are of the truthful". 50 That is why Lot (AS) called the inhabitants of this so-called modern and enlightened society as "ignorant and overly obscene". ${ }^{51}$ When they did not repent despite the teachings of their Prophet Lot (AS) $,{ }^{52},{ }^{53},{ }^{54}$ he sought help from Allah Almighty Who rained stones on his people and wiped them out". 


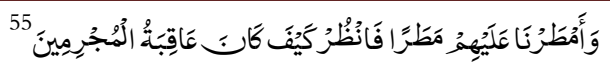

"And We rained down on them a great rain. So see what the end of the criminals was"!

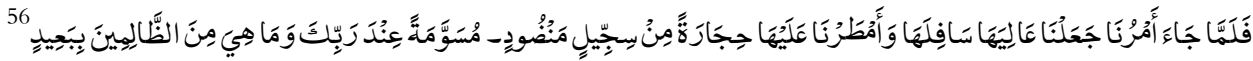

"Whenever Our command came, we lowered the upper part of it and threw stones at them in layers. Those who were marked by your Lord, and they are not far from the wrongdoers".

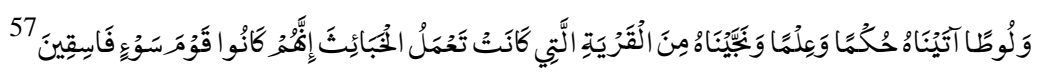

"And Lot (AS), We gave him command and knowledge and transported him from the town which used to be the epicenter of evil deeds. Surely they were a rebellious people".

\section{The Logical Aspect of Sex Education: The Disadvantages of Forbidden Sex}

Having sex without marriage is illegal, unfair and extremely harmful to the individual and society. The increasing number of sexual exploitation cases has become the norm in Western society. Due to gang rape, free sex activities, prostitution, homosexuality, etc., the number of patients with deadly diseases is increasing in Western countries. AIDS, gonorrhea, chlamydia, syphilis, and hepatitis B are among the top 10 in the list of 20 deadly diseases. In the United States and other developed countries people in majority aged between 25 to 44 die of these lethal diseases. ${ }^{58}$ According to a study conducted by the Atlanta Center for Disease Control and Prevention, as many as 12 million Americans become infected each year through sexual activity. Some organizations claim that half of the US population suffers from sexually transmitted diseases at the age of mere $35 .{ }^{59}$ According to the holy Quran and Hadith, adultery is one of the deadliest evils that destroys the family system of the human population, peace of mind, deprives children of the natural and sincere love of their parents, and most of them fall prey to drugs and other crimes as soon as they step on the threshold of adolescence. To protect Islamic society from all these harms, Allah Almighty has prescribed the punishment of flogging and stoning for adulterers.

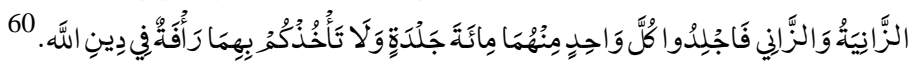

"The woman who commits adultery and the man, who commits adultery, flog each of them with 100 lashes and do not give any leniency to them in beating as Allah's religion allows it".

This punishment is a warning to other people so that they may learn a lesson from it. Those who practice these teachings, find success, peace, and spiritual satisfaction in their lives. In the Western world, sexual harassment has also led to low-risk pregnancies and miscarriages. Today, in the United States, about one million or more girls enter the process of unmarried pregnancy each year. Of these, about half of a million girls become mothers after completing the period of the pregnancy of their children, four and a half million girls get aborted and twenty-five thousand girls leave their children in welfare centers after giving birth to them. From where, the childless gentlemen come and adopt them. The birth rate of unmarried underage girls was $13.98 \%$ in 1950 
but increased to $59 \%$ in 1985 in USA. There is also a rumor that mothers of young girls are either black or belong to poor families. It is also a rumour that 2 out of every 3 girls who become mothers are either black form or who belong to poor and deprieved families. Now 2 out of every 3 girls who become mothers are white form lasses and belong to urban areas while they are counted among the wealthy people. Of the 54,000 women serving in the US Navy, the pregnancy rate is 40 percent, in comparison to general population where it is just 17 percent. What is the life of a girl who gets pregnant at a young age? It must be despondent and worrisome. Only 50\% girls complete high school education. About $50 \%$ of the girls rely on charity organizations. These girls are further sexually exploited and $82 \%$ of the children who come into the world through them, also become victims of sexual abuse till puberty. According to US statistics, 8.6 billion dollars are spent each year on the care and financial support of these young mothers. ${ }^{61}$

\section{Conclusion:}

Sexual intercourse between men and women is considered necessary for the birth of a new generation all over the world. Intercourse can never be aboided by human beings as it is dangerous. Sexual activity, just like human interaction, social discipline, birth and death, has also adopted the form of strict questions. It is not possible to escape away from these questions, so the religious institutions have begun to take responsibility for answering them. Different religions have different types of sexual ethics in the light of which specific rules regarding sexual relations are formulated in societies. Islam, Judaism, Christianity, Hinduism and Buddhism have introduced strict ethical rules regarding sexual behavior. It is considered wrong to adopt methods that contradict these already set rules and regulations. Here it is important for us to understand that according to Islamic teachings, the purpose of sexual intercourse is to establish a relationship of love and affection between two opposite sex people, to satisfy each other, to create a bond between two families through one. It is to train the members of the society physically, mentally and psychologically and to bring the innate relations between human beings around the world to a balanced extent. The secular view regarding sexuality is incomplete because it does not cover all aspects of sexual ethics, including marriage. The ultimate solution to sexual exploitation is present in the holy Quran by introducing punishments and retributions. It has banned all sexual evils. The holy Quran has expressed serious concern about sexuality. It is subject to marriage and family affairs at every level. Sexual intercourse in married life is a reward which is given by Almighrty Allah. Sexual intercourse outside the limits of marriage is a punishable crime. This law cannot be changed because of social behavior or pressure groups. Therefore, like other Islamic teachings, knowledge about sexuality is very important for Muslims so that they may not go astray and act against the commandment of the Creator of this entire universe. 


\section{References:}

${ }^{1}$ Macdonald, Donald Ian, An Approach to the Prevention of Teenage Pregnancy, July/August 1987

${ }^{2}$ Joseph, Bristow, Sexuality, Routledge, 1997, P. 03

${ }^{3}$ Oxford Advanced Learner's Dictionary, 2002, p.1220

${ }^{4}$ Sextuality, P. 01-03

${ }^{5}$ Yaseen :36

${ }^{6}$ Alroom :21

${ }^{7}$ Alnaba :8

${ }^{8}$ Muslim Ibn Hajjaj Al-Qushayri, Sahih Muslim, Hadith \# 2329, Dar Al-Salam, Lahore, 2012

${ }^{9}$ Al-Baqarah: 187

${ }^{10}$ Almursalat 20 to 23

${ }^{11}$ Altareq 7-8

${ }^{12}$ Abdullah Yusuf Ali, The Holy Quran, Amana Corp, Maryland, 1983, P.1719

${ }^{13} \mathrm{Al}$ muminun $12-14$

${ }^{14}$ Alnakhal $12-15$

${ }^{15} \mathrm{Al}$ zareyat 56

${ }^{16} \mathrm{https}: / / \mathrm{www}$.plannedparenthood.org

${ }^{17}$ CNN NEWS. Abstinence programs no guarantee, CNN, Associated Press, April 2007

${ }^{18}$ Jon, Slater Britain, Sex Education, Under Fire, UNESCO, Courier, July-Agust, 2000

${ }^{19}$ Ibid

${ }^{20}$ Guus, Valk, The Dutch Model, UNESCO, July-Agust, 2000

${ }^{21}$ Mehta, Suman, Adolescents in Changing Times, Bangkok, Thailand, 24-27 March, 1998

${ }^{22} \mathrm{HIV}$ prevalence rate among 13-19 year olds in Masaka, Uganda.

http://www.who.int/inf-new/aids2.htm

${ }^{23}$ Luqman: 19

${ }^{24}$ Hashim, Syed Mansur, What Boucher did in Dhaka, Dhaka Courier Issue 03, 11 Agust 2006, Vol. 23, P. 09

${ }^{25} \mathrm{Al}$ tuzeh bil reyaz 2013

${ }^{26}$ Abdul Rahim Omran, Family Planning in the legacy of Islam, Routledge, (1994), New York, P.14

${ }^{27} \mathrm{AL}$ rum $: 21$

${ }^{28} \mathrm{Al}$ araf 189

${ }^{29} \mathrm{Al}$ noor 33

${ }^{30}$ Abu Abdullah Muhammad Bin Ishih Al-Bukhari, Hadith No. 5mail Al-Bukhari, Sa065, Rashidia Library, Delhi

${ }^{31} \mathrm{http}$ ://fathersforlife.org/education/home_schooling.htm

${ }^{32}$ Dr. Shahid Athar, Sex Education for Muslim Youths and Their Parents, http://www.islam-usa.com/im20.html

${ }^{33}$ Dr Mihammad Kutub, Sexuality in Islam, University of Maimonides, 2004, P. 154

${ }^{34}$ Muhammad Rawas Qala, Dictionary of Jurists, Page No. 154, Dar Al-Nifais, Beirut, 1996

${ }^{35} \mathrm{Al}$ baqra: 223

${ }^{36} \mathrm{Al}$ baqra:222 


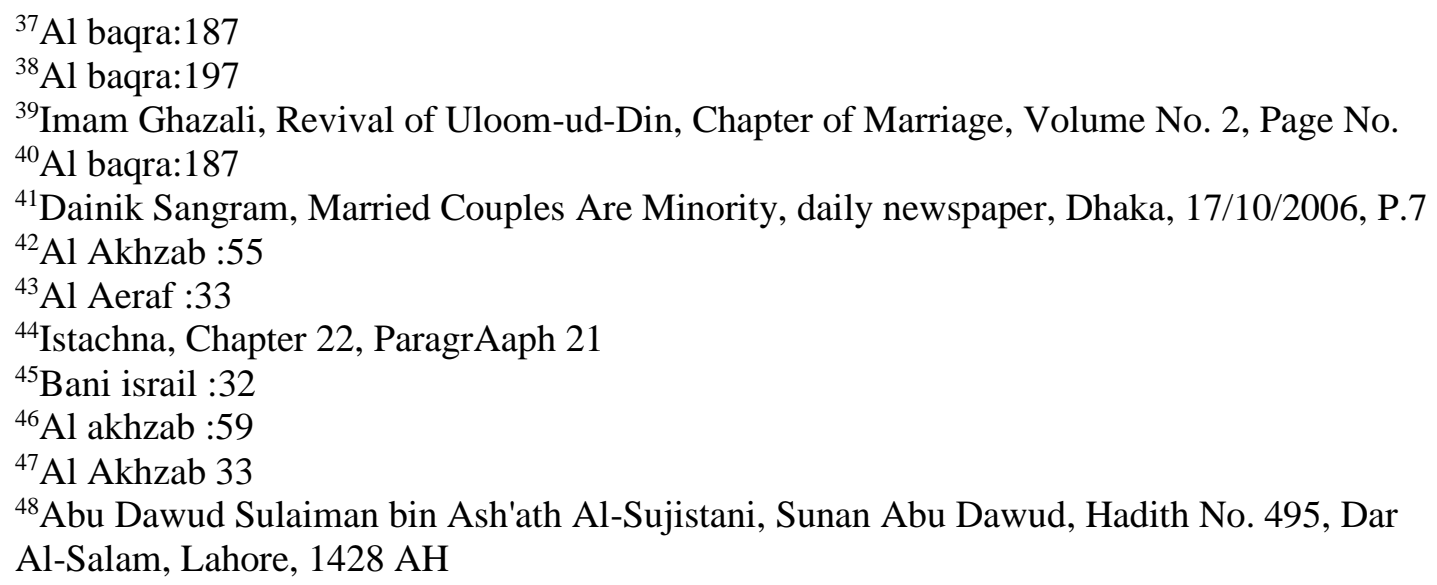

${ }^{61}$ Sandfort et al, Same-Sex Sexual Behavior and Psychiatric Disorders: Findings from the Netherlands Mental Health Survey and Incidence Study (NEMESIS), the Archives of General Psychiatry ‘January 2001 